\title{
MEASURES IMPLEMENTED BY LOCAL AUTHORITIES, PARTICULARLY \\ IN THE SPHERE OF SPATIAL POLICY, AND ITS IMPACT ON SETTING UP AND DEVELOPING COMPANIES - OPINIONS COMPARISON*
}

\author{
Izabela Rogalska, $\mathrm{MSc}^{1}$ \\ Renata Marks-Bielska, Ph.D. Eng., Associate Professor ${ }^{2}$ \\ University of Warmia and Mazury in Olsztyn \\ Faculty of Economics \\ Department of Economic Policy \\ M. Oczapowskiego 4, 10-719 Olsztyn, Poland \\ ${ }^{1}$ e-mail: izabela.rogalska@uwm.edu.pl \\ ORCID: 0000-0002-2614-5967 \\ 2 e-mail: renatam@uwm.edu.pl \\ ORCID: 0000-0001-7319-1918
}

Received 3 October 2019, Accepted 21 March 2020

\begin{abstract}
Research background: The development of business on a local level depends on a variety of factors, which as is often the case are shaped by the local authorities. An example of activities carried out by local governments in order to help develop businesses is the management of the spatial resources in a given municipality in such a way as to facilitate starting and developing companies.

Purpose: The principal objective of this study has been to identify how local authorities and businessmen perceive the role of conditions associated with the municipality's spatial policy in terms of starting and conducting a business.

Research methodology: The research results rely on primary data acquired by conducting a survey based on a questionnaire designed by the authors.

Results: The results permitted to demonstrate differences and similarities among the opinions of our respondents concerning factors linked to the spatial policy of a municipality that have an impact on decisions to set up and develop companies. Among the location factors, the most important ones, according to both local governments and businessmen, were the state of the local infrastructure, such as IT, transportation, communication, waterworks and sewers, power supply.
\end{abstract}

\footnotetext{
${ }^{*}$ The research results presented in the article were received as part of the implementation of the research project entitled The role of the institutional business environment in business location. The project was financed by the National Science Centre, Poland, project registration number: 2016/23/N/HS4/01943.
} 
Novelty: The confrontation of the replies provided by local authorities and by entrepreneurs concerns spatial policy, and the territorial scope of the research covering the whole of Poland, the different types of enterprises from various branches are the innovative element of the study.

Keywords: local development, entrepreneurship, business activity, local authorities, spatial policy

JEL calssification: O18, R11, R30

\section{Introduction}

An important stimulus to start and/or continue a business can come from local authorities, as all sorts of measures and actions they implement are the factors which create an environment for conducting economic activities. A well designed and implemented local policy, with such manifestations as creating an atmosphere conducive to investments or a desirable social climate, contributes to the development of economic entrepreneurship. In general terms, development embraces positive quantitative and qualitative changes. It is a process that relies on endogenous and exogenous factors. Local development, in turn, comprises coordinated and consistently implemented activities undertaken by the local community, public authorities and other players operating in the territory of a given municipality, whose aim is to create new and to improve existing useful assets, to shape suitable conditions for the economy, and to ensure spatial and ecological order (Graczyk, 2008; Wołowiec, Reśko, 2012).

In compliance with the guidelines of the World Bank, the UN and OECD countries, the purpose of local development is to build and activate the potential of a given territorial unit, e.g. a municipality, to attain a better economic future, and to improve the quality of life of local residents (Kisman, Tasar, 2014). In economic practice, it is particularly important to establish connections between the intentions of local authorities to develop the administrative unit they govern with the creation of suitable conditions for business entities operating in the same territory (for instance, by creating desirable location environments for the growth of the local economic sector) (Walzer, 2009). Obviously, local authorities cannot have direct influence on all conditions which encourage the influx of investments, such as the geographical location, local selling market, etc. However, they can produce a strong impact on such conditions as the state of technical infrastructure, technical state of office and production space available for possible investment projects, quality and efficiency of services provided by municipal clerks, 
right attitude of local authorities and community towards entrepreneurs, accessibility of areas dedicated to investment projects, building resources of professional workforce, e.g. by ensuring access to education, cooperation with R\&D institutions, assistance in making contact between investors and business environment institutions, and local tax incentives, etc. The influence of the above factors depends on diverse conditions and varies over time (Czaplewski, 2005). Researchers (including Baumol, 1990; Minniti, Lévesque, 2008; Shane, 2009; Williams, Shahid, 2016; Williams, Vorley, Williams, 2017) have proven the predominant impact of institutional support on business activity.

It is more and more often understood that a decision to localise an investment project and the risk associated with such a decision should be considered not only from the viewpoint of an investor, but also in terms of local governments and other entities functioning in a given local space, including real estate owners, local community, various institutions and others (Kuciński, 2014, pp. 9-12; Niedziółka, 2016). Chances that a company will achieve the aims set by its management are greater when the environment in which it operates is more predictable. The choice of a specific location for an investment and the subsequent functioning of a company in this space are influenced by location factors, that is a complex set of circumstances that occur both in the company and in its surroundings (Godlewska-Majkowska, 2016; Serocka, 2019).

The study by W. Karaszewski (2016), which was completed in Poland among representatives of companies with foreign capital and among local government officials implicates a constant need for local authorities to undertake greater efforts in order to improve the conditions in which business entities operate. It is important to notice and serve the needs of current and potential investors, willing to locate and manage companies in a given municipality. The structure of replies given by the respondents, for example in the Warmia and Mazury voivodeship, showed some difference in the perception of conditions for conducting business between foreign investors and local authorities, especially in areas connected with the direct intervention of a local government shaping the environment for entrepreneurship development, i.e. quality and efficiency of service in offices, local tax incentives and the approach of local authorities towards investors and investments. The self-evaluation by local authorities was positive, whereas the investors inquired were much more critical, which was reflected in considerable disproportions between the two analysed groups in terms of the final assessment.

One of the major location factors is the space and spatial management. The importance of this factor grows with the progressing spatial diversity of man's living environment, increasing complexity and growing deficit of space suitable for locating numerous functions needed by the community, and simultaneously with the growing conflict with natural resources and 
cultural heritage assets. Considering the above, local governments should implement systematic measures for the sake of rational use and management of space (Ziółkowski, 2005).

Economically speaking, space is an example of rare goods. It is an essential element needed to start and conduct any economic activity. Changes in the spatial management of a municipality are the changes in the conditions which underline the undertaking and developing local businesses. Local government is the principal subject that makes decisions about such changes, and that coordinates and supervises them. Local government can make decisions which will directly change the spatial management in their municipality. Provision of spatial order and management of land resources belong to tasks delegated to a municipality (Sztando, 2003). It is essential to prevent conflicts, which can arise between subjects competing for elements of space that can be used for various purposes, as regulated by law (Marks-Bielska, Lizińska, Babuchowska, Wojarska, 2017).

In practice, spatial management is governed by a number of legal provisions pertaining to the management of man's living environment by people, of which the basic role is played by the legal regulations concerning land use, protection of the natural environment, or management in general (Parysek, 1995). Instruments of a municipality's spatial management can have positive or negative effects on the functions performed in a municipality, including economic, social, environmental, and tourism-related ones. Spatial planning is one of the basic elements of strategic management in a municipality. It takes into account all spheres in which local subjects (local authorities, residents, entrepreneurs) function, and their impact on the surroundings (Szaja, 2016).

Local governments are more and more engrossed in the conscious creation of conditions for economic growth in local and regional space. They employ numerous instruments and approaches to stimulate entrepreneurship, which plays an important role in the socio-economic development (Williams et al. 2017). The essential question that remains to be resolved is how such tools and methods will be incorporated in the long-term and coherent business support policy, seen from the demand side with the focus on how, where and why new companies are founded. What seems to matter here is the stability of created conditions and the extent to which these respond to the demand declared by entrepreneurs. In order to tap and reinforce the identified potential properly, local authorities need to assume a perspective approach, without which all undertaken activities would be haphazard, lacking continuity and long-term prospects, thereby being hardly effective (Skica, Bem, 2014).

While implementing entrepreneurship development programmes, local governments often cooperate with the existing companies. Some obvious consequences of such collaboration are: 
- local authorities gain the knowledge of the companies' needs and possibilities for development, which enables the municipal government to create conditions which facilitate business activity in their territorial unit,

- entrepreneurs become engaged in solving problems of the municipality,

- local governments of administrative units carry out promotional activities together, both on a national and international scale,

- local authorities and companies undertake mutual investments as public-private partnerships, for example in housing, tourism, etc.

One of the forces which incline the existing companies to act in a way expected by the authorities of a given municipality consists of economic and financial instruments. The municipal budget plays the most important role among the financial instruments that a municipality has at its disposal. The budget is adopted by the council of a municipality annually, in compliance with strictly defined procedures (Sobczak, 2000). However, many municipalities are struggling with financial problems and local development in general and often leads to unemployment and lack of entrepreneurship development. This is often associated with the asymmetrical distribution of regional public investments. It's a result of favoring larger cities and a much greater concentration there, among others business (Davis, Henderson 2003; Orłowska, 2017).

An extremely significant component of the municipal budget comprises investment expenditures, which contribute to the improved investing attractiveness of a given territorial unit, and mainly entail investments in the technical and social infrastructure. An adequately high level of the available infrastructure is a necessary condition for the proper economic state and development of a given area. Infrastructural instruments are mostly ones which maintain and develop the technical infrastructure (waterworks, sewers, electric power and heat energy supply, public transport), and social infrastructure (education, culture, health service). Investing in infrastructure reinforces the position of a municipality as a subject which acquires new investors or retains existing companies in its territory (Zawora, 2016).

The efficient and effective performance of own tasks by a municipality requires appropriate tools and financial means as well as their skilful application. The available tools have either direct or indirect influence. The municipal authorities can therefore regulate directly activities carried out by the companies operating in a given area (for instance, through resolutions, decisions, spatial management studies and plans), but they can also participate in such activities (economic activity, investments, selling tangible assets or real estate properties). The indirect influence includes such measures as shaping conditions for business activity (e.g. tax rates, 
contracts, agreements) (Marks-Bielska, 2017; Marks-Bielska, Kurowska, 2017; Marks-Bielska, Serocka, 2018).

Pro-development measures implemented in the sphere of local economic policy are most often aimed at retaining the existing companies and enabling their further growth, as well as creating conditions conducive to the establishment of new enterprises. Companies have influence on the economic space both on a local scale, by employing local production means, and regionally, through their economic connections. Entrepreneurs have long affected the supply of societal needs, for example by causing improvement in the quality of life of local inhabitants, hence economic activity is a necessary condition for initiating the economic growth (Hall, Daneke, Lenox, 2010; Typa, 2016).

The main objective of this study has been to determine how local authorities and entrepreneurs perceive the role of conditions connected with the spatial policy of a municipality in the context of developing business activity.

\section{Methodology}

The research results rely on primary data acquired by conducting a survey based on a questionnaire designed by the authors. The survey, addressed to local authorities and entrepreneurs, was conducted at the end of 2017 and completed at the beginning of 2018 . The questionnaires were posted to all municipalities in Poland (2,477). 1,257 correctly completed questionnaires were received, which ensured a $50.7 \%$ return rate $(10.7 \%$ of urban municipalities, $21.6 \%$ of urban-rural municipalities and $63.8 \%$ of rural municipalities, and $4.0 \%$ of cities with the status of a district).

Questionnaires were also posted to randomly selected non-financial enterprises in all of Poland (random method), with a workforce of at least 10 employees. According to the Central Statistical Office in Poland (GUS), there were 72,739 non-financial companies in Poland in 2017. Assuming the maximum error at 5\% and the level of trust at $95 \%$, the required number of companies which should participate in the study was at least 382 . In our study, 392 companies responded to the questionnaire, and therefore the research sample is to be considered as representative.

In order to interpret the collected primary data, simple statistical methods (mainly arithmetic average) were applied and the validity index used by Kola, Kujawska, Kuzel, Piotrowska-Trybull, Studzińska (2005) was calculated according to the formula: 


$$
W=\frac{\sum_{i=1}^{k} n_{i} w_{i}}{k \cdot N}
$$

where:

$W$ - validity index (the indicator takes values from 0 to 1 ; if its value is higher, the measure implemented by local authorities has been more important),

$i$ - evaluation index,

$n_{i}$ - number of indications of a given measure in the $i$-th place,

$w_{i}$ - evaluation corresponding to the location of the i measure,

$k$ - maximum rating on a scale from 1 to $k$,

$N-$ the number of respondents who answered the question.

The results were collated and interpreted with the help of tables and descriptions of the data.

\section{Research results}

Among the factors which affect local development there is an increase in the level of entrepreneurship, which depends on the conditions in which potential or existing enterprises operate in a given area, i.e. on the investment attractiveness of this area. The investment attractiveness of a municipality is in turn affected by local authorities, for example by shaping the local spatial policy. Because investment attractiveness is connected with the development of entrepreneurship, the questionnaire contained a request addressed to local authorities to compare the level of entrepreneurial development with the investment attractiveness of the municipality they governed. A considerable percentage of the respondents $(63.4 \%)$ concluded that this level was adequate to the investment attractiveness of their municipality, whereas $29.3 \%$ assessed it to be lower than investment attractiveness, and 6.3\% stated that it was higher than investment attractiveness (Table 1).

The research results are quite optimistic because the level of entrepreneurship development being adequate to investment attractiveness can mean that local authorities were satisfied with the present economic situation in $63.4 \%$ of the municipalities. It would be worth pondering whether the level of entrepreneurship lower than investment attractiveness diagnosed in nearly every third municipality was a consequence of the excessively high expectations of local authorities, or if it depended on the type of municipalities and territories for investment. When 
Table 1. Adequacy of the level of entrepreneurship development to investment attractiveness according to local authorities

\begin{tabular}{|c|c|c|c|c|c|c|c|c|c|c|}
\hline \multirow{3}{*}{$\begin{array}{c}\text { The level of entrepreneurship } \\
\text { development }\end{array}$} & \multicolumn{10}{|c|}{ Type of municipality (\%) } \\
\hline & \multicolumn{2}{|c|}{ in total } & \multicolumn{2}{|c|}{$\begin{array}{l}\text { city with } \\
\text { the status } \\
\text { of a district }\end{array}$} & \multicolumn{2}{|c|}{ urban } & \multicolumn{2}{|c|}{ urban-rural } & \multicolumn{2}{|c|}{ rural } \\
\hline & $\mathrm{N}$ & $\%$ & $\mathrm{~N}$ & $\%$ & $\mathrm{~N}$ & $\%$ & $\mathrm{~N}$ & $\%$ & $\mathrm{~N}$ & $\%$ \\
\hline $\begin{array}{l}\text { Higher than investment } \\
\text { attractiveness }\end{array}$ & 79 & 6.3 & 7 & 14.0 & 11 & 8.2 & 14 & 5.1 & 47 & 5.9 \\
\hline $\begin{array}{l}\text { Adequate to the investment } \\
\text { attractiveness }\end{array}$ & 797 & 63.4 & 36 & 72.0 & 99 & 73.9 & 170 & 61.8 & 492 & 61.7 \\
\hline $\begin{array}{l}\text { Lower than investment } \\
\text { attractiveness }\end{array}$ & 368 & 29.3 & 7 & 14.0 & 24 & 17.9 & 86 & 31.3 & 251 & 31.5 \\
\hline No answer & 13 & 1.0 & 0 & 0.0 & 0 & 0.0 & 5 & 1.8 & 8 & 1.0 \\
\hline
\end{tabular}

$\mathrm{N}$ - Number of Communes.

Source: author's own survey research.

analysing the research results divided between the types of municipalities, certain differences were observed. The above assessment, i.e. the level of entrepreneurship adequate to or lower than investment attractiveness was more frequent among rural municipalities (61.7 and 31.5\%, respectively) and urban-rural ones (61.8 and 31.3\%). The results of our survey may originate from various types of circumstances. The level of entrepreneurship development depends on numerous conditions - it is relatively easy to set up, maintain and develop a business activity near or in a city than in rural areas. Moreover, urban municipalities with their relatively higher revenues can invest more, for example to develop land for investment projects, or to employ an official who will take care of providing complex services to investors. One should also consider the quality of roads in rural areas. Although it has improved over recent years, they are still inferior to those of district or provincial roads, and this is also taken into consideration when selecting a location for a new business. Recapitulating, local authorities in areas that are less developed should constantly strive, to the extent achievable to them, to have a positive influence on the development of entrepreneurship. Even if a local government lacks funds allocated to this purpose, it can still affect decisions made by potential investors in other ways, e.g. by instilling in municipal officials the right attitude into the mindset of entrepreneurs. And although this aspect may seem less important, time and again it turns out that so-called soft factors play an enormous role in starting and conducting a business (Budner, 2004, pp. 24-41).

Measures undertaken by local authorities to improve the level of entrepreneurship most often bring about expected results. However, there are cases when these outcomes are negligible or completely absent. A question therefore arises: to what extent do local authorities actually 
produce an effect on decisions to start and carry out a business activity? The respondents (both local authorities and entrepreneurs) were asked to evaluate the question on a scale from 1 to 10 (Table 2). The answers showed that entrepreneurs perceive this problem differently than local government representatives, as the officials assessed the actual impact of local authorities at 6.1 (moderate influence), whereas the businessmen scored it lower, at 4.9 (very small effect). Entrepreneurs evaluated the actual effect of actions undertaken by local authorities lower than the representatives of local governments did.

Table 2. Evaluation of the actual effect of measures implemented by local governments on starting and conducting business activity

\begin{tabular}{|l|c|c|c|c|c|}
\hline \multirow{2}{*}{ Average rating of impact by } & \multicolumn{5}{|c|}{ Type of municipality } \\
\cline { 2 - 6 } & in total & $\begin{array}{c}\text { city with } \\
\text { the status } \\
\text { of a district }\end{array}$ & urban & urban-rural & rural \\
\hline Local Authorities & 6.1 & 7.3 & 6.7 & 6.5 & 5.7 \\
\hline Entrepreneurs & 4.9 & 5.7 & 5.2 & 5.0 & 4.5 \\
\hline
\end{tabular}

Key to the scale: 1.0-2.9 very small, 3.0-4.9 small, 5.0-6.9 moderate, 7.0-8.9 strong, 9.0-10.0 very strong effect of the actions undertaken by local authorities on decisions to start and conduct business activity.

Source: author's own survey research.

Considering the results obtained from our survey, it is justifiable to claim that local authorities may overrate their assessment of the actual effect they have on the development of entrepreneurship. On the other hand, the assessment made by businessmen can arise from the fact that they either do not appreciate or miss to notice the efforts made by local governments to support them. However, having considered the experiences of both sides, it needs to be concluded that unfortunately the actions carried out by local authorities, according to entrepreneurs, have a very small influence on the development of entrepreneurship. Furthermore, when the research results were scrutinised according to the four distinguished types of municipalities, then the assessment of the said influence yielded lower scores in rural and urban-rural municipalities than in towns and cities, and the average score was raised countrywide by responses collected from cities with the status of a district.

An important type of measures implemented by local authorities in order to assist in starting and running businesses is the spatial management of a municipality in its broad sense. Such actions need not be directly aimed at reaching some improvement in the conditions for conducting economic activity, but their implementation will ultimately have some influence on thereof. For instance, more efficient public transport, including better road infrastructure, 
not only affects the quality of life of local residents, but also changes the perception of the location as a site for investment. Better quality of roads can also contribute to the development of companies which already operate in a given area. Local authorities were asked to evaluate the importance of the measures they implemented which were directly or indirectly associated with the management of space in their municipality. Based on the scores assigned to the mentioned actions, an indicator of importance was calculated, which then enabled us to point to the most important actions having an impact on decisions to set up and to run companies (Table 3). According to local governments, generally the greatest importance (the highest value of the importance indicator) for decisions to start and conduct business activity should be ascribed to the following measures: development of land for investment (importance indicator at 0.86), active implementation of the municipality's spatial policy (0.82), construction/modernisation of fibre-optic Internet connections (0.81), active development of the municipality in terms of education, intellectual development and culture (0.81), and improved appeal of the municipality and its surroundings as a tourist destination (0.81). In fact, the development of land plots for investment projects (e.g. construction of waterworks, sanitary sewers, storm drains, power transmission lines, fibre- optic cables) makes it much easier to start a business. Furthermore, having a well-ordered legal status of land is extremely important as well. An entrepreneur who plans to set up a business, if having a choice between land with a well-ordered legal status or without it, in most cases will opt for the former alternative. The legal status of a real estate property is also important when a company has the chance to expand but the land use assigned to adjacent land plots does not permit it.

As the perception of the role of particular measures may depend on the type of a municipality represented by given local authorities, the importance indicator was calculated inclusive of the types of municipalities as well as the cities with the status of a district. The first issue which emerged quite distinctly was that values of the importance indicator depending on the type of municipalities were higher according to the local authorities of municipalities with the status of a district, urban and urban-rural municipalities. It is worth considering what may have caused this outcome. Local authorities in rural areas may have encountered situations where various measures they implemented had no effect on the development of entrepreneurship, and therefore they evaluated such actions much lower. When it comes to the ranking order of activities as set by the distinguished groups of municipalities (according to the indicator of importance), the outcome is slightly different. However, the reason is not the different assessment given to these activities, but very small differences in the achieved values of the importance indicator (of just a few hundred of a per cent). Hence, it is justified to claim that in many cases the hierarchy of activities inclusive of the division into types of municipalities was similar. 
Table 3. Validity index of measures connected with the spatial policy of a municipality, undertaken by local authorities, which have an influence on starting and conducting business

\begin{tabular}{|c|c|c|c|c|c|}
\hline \multirow{3}{*}{ Measures } & \multicolumn{5}{|c|}{ Type of municipality } \\
\hline & in total & $\begin{array}{l}\text { city with } \\
\text { the status } \\
\text { of a district }\end{array}$ & urban & urban-rural & rural \\
\hline & \multicolumn{5}{|c|}{ validity index } \\
\hline Improvement of public transport & 0.78 & 0.90 & 0.82 & 0.79 & 0.76 \\
\hline Construction/modernisation of a fibre-optic network & 0.81 & 0.87 & 0.83 & 0.82 & 0.80 \\
\hline Development of land for investment projects & 0.86 & 0.92 & 0.88 & 0.88 & 0.84 \\
\hline Shaping safe public spaces & 0.75 & 0.84 & 0.77 & 0.78 & 0.74 \\
\hline $\begin{array}{l}\text { Construction/modernisation of a wastewater treatment } \\
\text { plant }\end{array}$ & 0.80 & 0.81 & 0.78 & 0.82 & 0.80 \\
\hline $\begin{array}{l}\text { Active development of a municipality in terms } \\
\text { of education and culture (taking care of good } \\
\text { conditions to spend free time and rest) }\end{array}$ & 0.81 & 0.90 & 0.83 & 0.83 & 0.80 \\
\hline $\begin{array}{l}\text { Maintenance, renovation and refurbishment } \\
\text { of municipal housing resources }\end{array}$ & 0.64 & 0.74 & 0.68 & 0.69 & 0.62 \\
\hline $\begin{array}{l}\text { Active participation of a municipality in the local real } \\
\text { estate market (market transactions of selling, buying, } \\
\text { renting, leasing, donating real estate properties) }\end{array}$ & 0.68 & 0.80 & 0.71 & 0.72 & 0.65 \\
\hline $\begin{array}{l}\text { Active implementation of a municipality's spatial } \\
\text { policy (e.g. having a well-ordered legal status of local } \\
\text { land plots for sale) }\end{array}$ & 0.82 & 0.93 & 0.84 & 0.85 & 0.79 \\
\hline Making land, buildings, office space available & 0.70 & 0.87 & 0.75 & 0.71 & 0.68 \\
\hline $\begin{array}{l}\text { Improving the appeal of a municipality and its } \\
\text { surroundings as a tourist destination }\end{array}$ & 0.81 & 0.87 & 0.82 & 0.83 & 0.79 \\
\hline Real estate tax exemption & 0.69 & 0.81 & 0.73 & 0.75 & 0.66 \\
\hline
\end{tabular}

Note: Validity index - the indicator takes values from 0 to 1 ; if its value is higher, the measure implemented by local authorities has been more important.

Bold fonts highlight the highest values of the importance indicator in each type of municipality - the three highest positions

Source: author's own research.

In a description of the activities undertaken by local authorities in the context of entrepreneurship development, it is also necessary to identify these measures which in the opinion of municipal clerks had the least importance. The results of our survey indicate that both in total and divided between the four groups of municipalities, the least important measures were said to be: making land resources, buildings or office space contained in the municipal resources available (the importance indicator value according to all municipalities in total 0.70 ), real estate tax exemption (0.69), active participation of a municipality in the local real estate market, e.g. market operations of selling, buying, or renting and leasing properties, etc. (0.68), maintenance, repairs and modernisation of municipal housing resources (0.64). 
The choice of a location, type and size of a business activity is affected by a number of various factors, collectively known as location factors. Some are directly or indirectly connected with the management of spatial resources by a municipality. Perception of location factors in the context of entrepreneurship development by local authorities can serve as a reference point when selecting and implementing particular tasks. Thus, it is very important that the perception of the importance of location factors by local authorities overlap, as much as possible, the way entrepreneurs perceive their importance, as this proves that local authorities know the needs of business people. Our results show that the assessments of location factors associated with the spatial policy of a municipality given by the two groups were not much different (Table 4). However, it should be noted that local authorities evaluated the importance of all given location factors slightly higher than entrepreneurs did, but the difference was rather small, never exceeding one point on the adopted assessment scale. Among the location factors included in our questionnaire, the following were evaluated the highest on a 1 to 10 scale (by both local authorities and entrepreneurs): state of IT infrastructure, including access to broadband Internet and to mobile telephone networks (scores 8.9 and 8.7, respectively - much importance), state of transportation and communication infrastructure (8.9 and 8.5 respectively - much importance) and state of waterworks and sewers (scores 8.9 and 8.1 - much importance).

Table 4. Importance of location factors connected with a municipality's spatial policy according to local authorities and entrepreneurs

\begin{tabular}{|l|c|c|c|c|}
\hline \multicolumn{1}{|c|}{ Location factor } & $\begin{array}{c}\text { Local } \\
\text { authorities } \\
\text { evaluation }\end{array}$ & $\begin{array}{c}\text { Position } \\
\text { of factor in } \\
\text { the ranking }\end{array}$ & $\begin{array}{c}\text { Entrepreneurs } \\
\text { evaluation }\end{array}$ & $\begin{array}{c}\text { Position } \\
\text { of factor in } \\
\text { the ranking }\end{array}$ \\
\hline Condition of transport and communication infrastructure & 8.9 & $\mathbf{2}$ & 8.5 & $\mathbf{2}$ \\
\hline Condition of waterworks and energetic infrastructure & 8.9 & $\mathbf{3}$ & 8.1 & $\mathbf{3}$ \\
\hline $\begin{array}{l}\text { Condition of telecommunication technical infrastructure } \\
\text { (broadband internet access, cellular network availability) }\end{array}$ & 8.9 & $\mathbf{1}$ & $\mathbf{1}$ \\
\hline Investment offer (availability of investment areas) & 8.3 & 4 & 7.0 & 7 \\
\hline A municipality's spatial policy (actively implemented) & 8.2 & 5 & 7.5 & 4 \\
\hline State of the natural environment & 7.5 & 8 & 7.1 & 6 \\
\hline Free time and relaxation conditions & 7.3 & $\mathbf{9}$ & 6.2 & $\mathbf{9}$ \\
\hline Attractive image of the region & 7.7 & 6 & 6.6 & 8 \\
\hline Public order and safety & 7.6 & 7 & 7.3 & 5 \\
\hline Commune's housing policy & 6.8 & $\mathbf{1 0}$ & 5.7 & $\mathbf{1 0}$ \\
\hline Average rating in total & 8.0 & & 7.3 & \\
\hline
\end{tabular}

Key to the scale: 1.0-2.9 very little importance, 3.0-4.9 little importance, 5.0-6.9 moderate importance, 7.0-8.9 much importance, $9.0-10.0$ very much importance.

Source: author's own research. 
Considering the hierarchy of location factors connected with the spatial policy of a municipality, the results showed identical choices by local authorities and entrepreneurs with respect to the first three and the last two places. The three most important location factors according to all respondents were the same three factors mentioned above. The two least important factors were: conditions for spending leisure time (scores: 7.3 by local authorities -much importance, and 6.2 by entrepreneurs - moderate importance) and housing policy (6.8 and 5.7, respectively, moderate importance). It is worth noticing that factors scoring the lowest were still given quite high scores. According to business people, active implementation of the spatial policy of a municipality was an important factor, which they placed on the fourth highest position (score 7.5 - much importance) (local authorities placed the municipality's investment offer and availability of land for investment in fourth place; in the opinion of entrepreneurs it was less important, as it dropped to seventh place). This does not mean that local authorities underrate the importance of active implementation of the municipality's spatial policy; in fact, they gave it a higher score (8.2) than entrepreneurs did, even though it was placed on a relatively low position in the hierarchy.

An analysis of the research results concerning the importance and hierarchy of location factors related to the spatial policy of a municipality demonstrates that the replies given by the representatives of local governments and by entrepreneurs are quite convergent there was a similar hierarchy of the factors, which were given high scores by both groups of respondents. This can testify to the good knowledge of entrepreneurs' needs gained by local authorities, which in the future can be a reference point for local governments to select and implement particular measures to assist in the development of entrepreneurship on a local level.

\section{Conclusions}

The investment attractiveness of a given area is a product of various types of conditions, partly dependent on actions pursued by local authorities. Assuming that the development of entrepreneurship depends on the investment attractiveness of a given territory, what follows is the conclusion that the latter can be also shaped by this territorial unit's authorities, which create local policy. This research enabled us to determine how local authorities compare the level of entrepreneurship development with the investment attractiveness of their municipality. The majority of respondents $(63.4 \%)$ concluded that this level was adequate to investment attractiveness, while $29.3 \%$ evaluated the level of entrepreneurship development as being lower than investment attractiveness, and 6.3\% decided that it exceeded the level of investment 
attractiveness. Considering the research results inclusive of the types of municipalities studied, the largest share of municipalities whose local authorities decided that the level of entrepreneurship development was lower than investment attractiveness was composed of rural municipalities $(31.5 \%)$ and urban-rural ones (31.3\%). This could have been a consequence of the fact that rural and urban-rural areas receive fewer investment funds, and are therefore less attractive to potential investors than urban areas. Furthermore, the poor quality road infrastructure in some rural areas makes it more difficult to start new companies or to develop existing ones. However, this does not mean that local authorities should accept the relatively lower level of entrepreneurship; rather, they are advised to expose the assets of municipalities which they manage, and try to improve the conditions which favour the growth of companies, for example they can apply for various types of funds to improve roads, to train municipal officials in terms of services provided for investors, or to organise meetings with entrepreneurs in order to recognise their expectations.

The research results pertaining to the importance of measures implemented by local authorities that affect the establishment and operation of business entities showed that according to local authorities the greatest importance was had by the following factors: development of land for investment (the importance indicator at 0.86), active implementation of the municipality's spatial policy (0.82), construction/modernisation of a fibre-optic network (0.81), active development of a municipality in terms of education and culture (0.81), and improved appeal of the municipality and its surroundings as a tourist destination (0.81). The research results indicate that all actions connected with the management of a municipality's space were quite highly scored by the respondents (the lowest value of the importance indicator in all municipalities equalled 0.64 on a scale from 0 to 1 ). This result can suggest that local authorities are aware of how important such measures are in the content of developing entrepreneurship.

The location factors are all circumstances which have influence on the choice of a location, including the risk of locating a company and its further functioning in the chosen space. The research has brought to light the opinions expressed by both local authorities and entrepreneurs with respect to location factors. Among the factors listed in the questionnaire, on a scale from 1 to 10 , the greatest importance was attached to the state of information and telecommunication technology (scores of 8.9 by local authorities and 8.7 by entrepreneurs), state of transportation and communication infrastructure (scores 8.9 and 8.5 - much importance) and state of waterworks, sewers, and power transmission infrastructure (8.9 and 8.1, respectively - much importance). The research results concerning the importance and hierarchy of location factors can testify to the sound knowledge of the needs of entrepreneurs gained by local 
governments. Having recognised the needs of business investors, local authorities can direct some of the tasks they perform to the improvement of conditions for conducting economic activity in the territory of their municipality, in the direction that coincides with the expectations of entrepreneurs. In the future, this can lead to a greater number of companies set up in a given area, and to the development of both new and existing enterprises.

\section{References}

Acs, Z.J., Desai, S., Hessels, J. (2008). Entrepreneurship, Economic Development and Institutions. Small Bus Economics, 31 (3), 219-234. DOI: 10.1007/s11187-008-9135-9.

Baumol, W.J. (1990). Entrepreneurship: Productive, Unproductive, and Destructive. Journal of Political Economy, 98 (5), Part 1, 893-921.

Budner, W. (2004). Lokalizacja przedsiębiorstw. Aspekty ekonomiczno-przestrzenne i środowiskowe. Poznań: Wydawnictwo Akademii ekonomicznej w Poznaniu.

Czaplewski, L. (2005). Działania samorządów lokalnych województwa kujawsko-pomorskiego na rzecz podniesienia atrakcyjności inwestycyjnej regionu w celu pozyskania bezpośrednich inwestycji zagranicznych. In: W. Karaszewski (ed.), Bezpośrednie inwestycje zagraniczne w podnoszeniu konkurencyjności polskiej gospodarki. Praca zbiorowa (pp. 165183). Toruń: Wydawnictwo Uniwersytetu Mikołaja Kopernika w Toruniu.

Davis, J.C., Henderson, J.V. (2003). Evidence on the political economy of the urbanization process. Journal of Urban Economics, 53 (1), 98-125. DOI: 10.1016/S0094-1190(02)00504-1.

Gaczek, W.M. (2003). Zarządzanie w gospodarce przestrzennej. Poznań: Oficyna Wydawnicza Branta, Bydgoszcz.

Godlewska-Majkowska, H. (2016). Monitorowanie ryzyka lokalizacji w lokalnych jednostkach samorządu terytorialnego. In: K. Kuciński (ed.), Lokalizacja działalności gospodarczej a jej ryzyko (pp. 161-193). Warszawa: CeDeWu.

Graczyk, M. (2008). Zarządzanie inwestycjami komunalnymi. Bydgoszcz-Zielona Góra: Oficyna Wydawnicza Branta.

Hall, J.K., Daneke, G.A., Lenox, M.J. (2010). Sustainable Development and Entrepreneurship: Past Contributions and Future Directions. Journal of Business Venturing, 25 (5), 439-448. DOI: 10.1016/j.jbusvent.2010.01.002.

Karaszewski, W. (ed.) (2016). Bezpośrednie inwestycje zagraniczne w wybranych województwach Polski - analiza porównawcza. Toruń: Wydawnictwo Uniwersytetu Mikołaja Kopernika.

Kisman, Z.A., Tasar, I. (2014). The Key Element of Local Development. Procedia Economics and Finanse, 15, 1689-1696. DOI: 10.1016/S2212-5671(14)00642-X. 
Kola, M., Kujawka, M., Kuzel, M., Piotrowska-Trybull, M., Studzińska, K. (2005). Metodyka badań. In: W. Karaszewski (es.), Bezpośrednie inwestycje zagraniczne $w$ województwie kujawsko-pomorskim. Stan, znaczenie dla gospodarki województwa, stymulanty i destymulanty napływu (pp. 26-38). Toruń: Uniwersytet Mikołaja Kopernika.

Kuciński, K. (ed.) (2014). Ryzyko lokalizacji przedsiębiorstw w Polsce. Warszawa: CeDeWu.

Lahutta, D. (2018). Analysis of the Entrepreneurship Level and Attitude in the Aspect of Starting-up and Running Micro-Enterprises among Students of Lublin Universities of Majors in Economics, Management, and Finance. Folia Oeconomica Stetinensia, 18 (1), 54-66. DOI: $10.2478 /$ foli-2018-0005.

Marks-Bielska, R. (2017). The Role of Local Authorities in Creating Conditions for the Development of Economic Activities: a Case Study of Rural Municipalities in Poland. Proceedings of the 8 th International Scientific Conference Rural Development 2017. DOI: 10.15544/RD.2017.249.

Marks-Bielska, R., Kurowska, K. (2017). Institutional Efficiency of Communes in Poland Respect of Space Management. Conference Proceedings of 17th International Multidisciplinary Scientific Geoconference SGEM 2017. Ecology, Economics, Education and Legislation, 17 (53), 521-528.

Marks-Bielska, R., Lizińska, W., Babuchowska, K, Wojarska, M. (2017). Factors Determing the Institutional Efficiency of Self-governments in the Economic and Spatial Area. Barometr Regionalny. Analizy i Prognozy. 15 (1), 67-75.

Marks-Bielska, R., Serocka, I. (2018). The Impact of Warmia and Masuria Local Authorities on Entrepreneurship Development in the Business Location Factors Context. Folia Oeconomica Stetinensia, 18 (1), 67-81. DOI: 10.2478/foli-2018-0006.

Minniti, M., Lévesque, M. (2008). Recent Developments in the Economics of Entrepreneurship. Journal of Business Venturing, 23 (6), 603-612. DOI: 10.1016/j.jbusvent.2008.01.001.

Niedziółka, D. (2016). Ryzyko lokalizacji elektrowni wiatrowych. In: K. Kuciński (ed.), Lokalizacja działalności gospodarczej a jej ryzyko (pp. 17-58). Warszawa: CeDeWu.

Orłowska, J. (2017). Czynniki i bariery rozwoju lokalnego. In: E. Gruszewska, K. Karpińska, A. Protasiewicz (eds.), Wspótczesne problemy ekonomiczne $w$ badaniach młodych naukowców. T. 1, Wzrost, rozwój i polityka gospodarcza (pp. 44-56).

Parysek, J.J. (1995). Podstawy gospodarki lokalnej. Poznań: Wydawnictwo Naukowe UAM.

Ramírez-Alesón, M., Fleta-Asín, J. (2016). Is the Importance of Location Factors Different Depending on the Degree of Development of the Country? Journal of International Management, 22 (1), 29-43. DOI: 10.1016/j.intman.2015.10.002.

Shane, S. (2009). Why Encouraging More people to Become Entrepreneurs is Bad Public Policy. Small Business Economics, 33 (2), 141-149. DOI: 10.1007/s11187-009-9215-5. 
Skica, T., Bem, A. (2014). Rola samorządu terytorialnego w procesach stymulowania przedsiębiorczości. Studia Regionalne i Lokalne, 1 (55), 79-92. DOI: 10.7366/1509499515505.

Serocka, I. (2019). Evaluation of Location Factors of Businesses by Local Authorities of Eastern Poland, with a Particular Emphasis on Spatial Policy. Real Estate Management and Valuation, 27 (1), 49-58. DOI: 10.2478/remav-2019-0005.

Sobczak, T. (2000). Pozyskiwanie środków finansowych na inwestycje komunalne. In: Z. Szymla (ed.), Konkurencyjność miast i regionów. Kraków: Wydawnictwo AE.

Szaja, M. (2016). Lokalna gospodarka przestrzenna w aspekcie planowania wieloletniego. Finanse, Rynki Finansowe, Ubezpieczenia, 6 (84/2), 99-111. DOI: 10.18276/ frfu.2016.6.84/2-09.

Sztando, A. (2003). Progospodarcza polityka przestrzenna gmin. Prace Naukowe Akademii Ekonomicznej we Wrocławiu. Gospodarka lokalna w teorii i praktyce, 979, 193-201.

Targalski, J., Francik, A. (eds.) (2009). Przedsiębiorczość i zarzadzanie firmą. Teoria i praktyka. Warszawa: Wydawnictwo C.H. Beck.

Typa, M. (2016). Rola przedsiębiorstw w rozwoju lokalnym i regionalnym. Prace Komisji Geografii Przemystu Polskiego Towarzystwa Geograficznego, 30 (1), 62-75.

Walzer, N. (ed.) (2009). Entrepreneurship and Local Economic Development. LEXINGTON BOOKS, United Kingdom.

Wiklund, J., Nikolaev, B., Shir, N., Foo, M., Bradley, S. (2019). Entrepreneurship and Wellbeing: Past, Present, and Future. Journal of Business Venturing, 34 (4), 579-588. DOI: 10.1016/j.jbusvent.2019.01.002.

Williams, C.C., Shahid, M.S. (2016). Informal Entrepreneurship and Institutional Theory: Explaining the Varying Degrees of (In)formalization of Entrepreneurs in Pakistan. Entrepreneurship \& Regional Development, 28 (1-2), 1-25. DOI: 10.1080/08985626.2014.963889.

Williams, N., Vorley, T., Williams, C.C. (2017). Entrepreneurship and Institutions. The Causes and Consequences of Institutional Asymmetry. London: Rowman \& Littlefield International.

Wołowiec, T., Reśko, D. (2012). Strategia rozwoju gminy jako narzędzie zarządzania zmianą gospodarczą. Zeszyty Naukowe WSEI seria: EKONOMIA, 5 (2), 61-89.

Zawora, J. (2016). Ekonomiczno-finansowe instrumenty gospodarczego rozwoju lokalnego. Przedsiębiorstwo i Region, 8, 76-87. DOI: 10.15584/pir.2016.8.8.

Ziółkowski, M. (2005). Zarządzanie strategiczne w polskim samorządzie lokalnym. In: A. Zalewski (ed.), Nowe zarządzanie publiczne w polskim samorzadzie terytorialnym (pp. 75133). Warszawa: SGH. 